\title{
Effectiveness reduction of nucleopolyhedrovirus against Chrysodeixis includens days after application in soybean plants
}

\author{
Ana Beatriz Riguetti Zanardo Botelho', Ivana Fernandes da Silva², Crébio José Ávila ${ }^{3}$ \\ ${ }^{1}$ Universidade de São Paulo, Escola Superior de Agricultura Luiz de Queiroz, Piracicaba, São Paulo, Brasil. E-mail: \\ biazanbotelho@gmail.com \\ ${ }^{2}$ Universidade Federal da Grande Dourados, Dourados, Mato Grosso do Sul, Brasil. E-mail: ivanaf.silva@ hotmail.com \\ ${ }^{3}$ Empresa Brasileira de Pesquisa Agropecuária - Embrapa Agropecuária Oeste - CPAO, Dourados - MS, Brasil. E-mail: \\ crebio.avila@embrapa.br
}

Received: 09/08/2018; Accepted: 18/09/2018.

\begin{abstract}
The use of nucleopolyhedroviruses (NPVs) can provide an effective and environmentally benign alternative to synthetic chemicals. The efficacy and persistence of their occlusion bodies may be affected by several factors. The present study investigated the efficacy of isolate Chin-IA (I-A) (ChinSNPV) on third-instar Chrysodeixis includens larvae after 10 days of its application in soybean plants under semi-field conditions. Two concentrations of virus $\left(2 \times 10^{11}\right.$ and $\left.10 \times 10^{11} \mathrm{PIB} \mathrm{ha}^{-1}\right)$ and water (control treatment) were applied in soybean plants. Leaves were collected $0,2,4,6,8$ and 10 days after application of treatments, and then used as disc format to feed the soybean looper larvae in the lab. It was considered a split plot scheme with a randomized complete block design (three treatments and eight repetitions) and the mortality data adjusted to a regression equation using the exponential decay model. In the day of application, the lowest and highest virus concentration caused 87.5 and $100 \%$ of mortality of larvae, respectively. However, their efficiency was reduced, on average, $70 \%$ after four days of the application. Among the factors may have compromised the persistence and activity of the isolate studied, the time after its application and ultraviolet radiation may have had a strong influence on this results. Its notable the potential use of ChinSNPV in programs for the management of this pest in soybean. Similarly, the properly application of this virus at sundown will ensure its efficiency for an extended period.
\end{abstract}

Keywords: Microbial control, Virus, Soybean looper, Climatic conditions, Loss of activity.

\section{Redução da eficiência do nucleopoliedrovirus contra Chrysodeixis includens dias após aplicação em plantas de soja}

\section{RESUMO}

O uso do Nucleopoliedrovirus (NPVs) pode fornecer alternativa eficaz e ambientalmente benéfica aos produtos químicos. A eficiência e persistência dos seus corpos de oclusão podem ser afetadas por diversos fatores. O presente estudo investigou a eficácia do isolado Chin-IA (I-A) (ChinSNPV) sobre lagartas de terceiro instar de Chrysodeixis includens após 10 dias da sua aplicação em plantas de soja sob condições de semicampo. Duas concentrações do vírus $\left(2 \times 10^{11}\right.$ e $\left.10 \times 10^{11} \mathrm{CPI} \mathrm{ha}^{-1}\right)$ e água (tratamento controle) foram aplicadas nas plantas de soja. Folhas foram coletadas 0, 2, 4, 6, 8 e 10 dias após a aplicação dos tratamentos, e fornecidas em formato de discos para alimentar lagartas no laboratório. Foi considerado um esquema de parcelas subdivididas com blocos aleatorizados (três tratamentos e oito repetições) e os dados de mortalidade foram ajustados na equação de regressão usando o modelo exponencial de decaimento. No dia da aplicação, a menor e maior concentração do vírus proporcionou 87,5 e $100 \%$ de mortalidade nas lagartas, respectivamente. No entanto, sua eficiência foi reduzida, em média, $70 \%$ após quatro dias da aplicação. Dentre os fatores que podem ter comprometido a persistência e atividade do isolado estudado, o tempo após a aplicação e radiação ultravioleta pode ter tido forte influência sobre os resultados. É notável o potencial do uso de ChinSNPV em programas de manejo para essa praga na soja. Da mesma forma, a adequada aplicação ao entardecer irá garantir sua eficiência por um período mais prolongado.

Palavras-chave: Controle microbiano, Vírus, Lagarta falsa-medideira, Condições climáticas, Perda de atividade. 
Brazilian grain production was estimated in 229.5 million ton to the $2017 / 2018$ harvest with soybean crops contributing with around 50\% (114.9 million ton) to this scenario (CONAB, 2018). Simultaneous with this large production, soybean producers have had significative economic losses due to the damages caused mainly by defoliating pests such as Chrysodeixis (= Pseudoplusia) includens (Walker, [1858]) (Lepidoptera: Noctuidae). The soybean looper, as it is known, was considered as a secondary pest. However, has become the primary soybean leaf eater in the past years possibly due to the increasing number of pesticide applications, especially those fungicides used to control Asian soybean rust, Phakopsora pachyrhizi Sydow \& P. Sydow, which has action against natural biological control agents, particularly the entomopathogen fungus Nomuraea rileyi (Farlow) (Bernardi et al., 2012).

The development of management strategies that integrate the potential of microorganisms may lead to a more effective control of this important defoliating pest. Among the microbial control agents, the virus of genus Nucleopolyhedrovirus (NPVs) from Baculoviridae family is a promisor candidate being highly virulent in laboratory and field conditions, persisting during years in the soil renewing the infecting cycles. NPVs represents a sustainable alternative to the environment, humans, pollinators and vertebrates (Moscardi et al., 2011). The $C$. includens Single Nucleopolyhedrovirus (ChinSNPV) was morphological and molecularly characterized by Alexandre et al., (2010). The authors have shown that, the virions present a single nucleocapsid per envelope occluded in a protein matrix, forming the occlusion bodies (OB). Furthermore, ChinSNPV's genetic diversity, phylogeny and the complete genome was revealed recently and compared with other Alphabaculoviruses (Craveiro et al., 2013; 2015).

The maintenance of $\mathrm{OB}$ integrity is crucial to viral persistence outside the host and for initiating infections in new host insects, thus some climatic factors may be limiting for its appropriate performance in the different agroecosystems (Stevenson et al., 2010). Solar radiation is the major factor affecting field persistence of baculoviruses with mean half-life generally ranging from 2 to 5 days (Moscardi et al., 2011; Jeyarani et al., 2013). Several studies reported the use of microencapsulation (Gifani et al., 2015) and UV protectants to prevent baculovirus inactivation such as reflectants (Wu et al., 2015), optical brighteners (Bernal et al., 2014), natural additives (Sutanto et al., 2017), and other general and selective absorbents, and chromophores (Beas-Catena et al., 2014). Temperature is another factor that can also affect the success of applied viruses by increasing the lethal time in regions with low mean temperatures, and by inhibiting the infection at low or high temperatures (Moscardi et al., 2011). Hence, timing of applications associated with an appropriate host age structure and density is a key feature for successful use of baculoviruses (Silva and Moscardi, 2002).

The present study was undertaken to investigate the efficacy of isolate Chin-IA (I-A) (ChinSNPV) on thirdinstar $C$. includens larvae days after its application in soybean plants under semi-field conditions. We made an association with the climatic conditions of the region with a view to provide better recommendations to use of this virus on soybean crops.

The experiment was carried out in semi-field conditions, during soybean crop 2016/2017 season, at Embrapa Western Agriculture located in Dourados city (22¹6'30"S, 5449'00"W, 408m), Mato Grosso do Sul State. Soybean plants from BRS 255 RR cultivar, adapted to edaphoclimatic conditions of region, were maintained in plastic vases (8L of capacity) containing a mixture (1:1:1) of land, sand and cattle manure under greenhouse conditions until to achieve the flowering stage (R2). The vases were then exposed to natural conditions being randomly placed under wooden structures. Two concentrations of isolate Chin-IA (I-A) (ChinSNPV) $\left(2 \times 10^{11}\right.$ and $\left.10 \times 10^{11} \mathrm{PIB} \mathrm{ha}^{-1}\right)$ and water (control treatment) were applied in soybean plants at 8 a.m. using a constant pressure bar $\left(\mathrm{CO}_{2}\right)$ sprayer equipped with empty cone nozzles and water volume equivalent to $100 \mathrm{~L} \mathrm{ha}^{-1}$. The isolate Chin-IA (I-A) was provided by Embrapa Soybean (Londrina/PR) and is considered one of the most pathogenic isolates to $C$. includens (Alexandre et al., 2010).

Leaves from the middle third of the plants, portion where soybean loopers remains mainly in field conditions (Czepak and Albernaz, 2014), were obtained in the day of application and two, four, six, eight and ten days after application of treatments (DAA). Soybean leaf discs were prepared (area of $12.56 \mathrm{~cm}^{2}$ ) using a metal hole-puncher with approximately $4 \mathrm{~cm}$ of diameter in the Entomology's laboratory. Third-instar C. includens larvae from an existing colony were placed in sterile plastic Petri dishes (1 larvae/Petri dish), fed with one soybean leaf disc and incubated in an environmental chamber at $25 \pm 2{ }^{\circ} \mathrm{C}$, relative humidity of $70 \pm 10 \%$ and photoperiod of 12L:12D. The leaf discs (not treated) were replaced every 48 hours until the death of larvae. Mortality was checked daily, and dead larvae were storage in eppendorf vials at $-20^{\circ} \mathrm{C}$.

A split plot scheme with a randomized complete block design was considered in this study comprising three treatments (two virus concentration and control) with a total of 10 soybean plants per treatment and eight 
replications (1 larvae/Petri dish). The evaluation times $(0,2,4,6,8$ and 10 days after application of treatments) corresponded to the subplots. The mortality results were submitted to variance analysis using the ASSISTAT program (Silva and Azevedo, 2002) and therefore, adjusted to a regression equation using the Exponential decay model with two parameters given by: $y=a . e^{-b . x}$ where, $\mathrm{y}=$ Average percentage of mortality (\%); $\mathrm{x}=$ Days after application of treatments (DAA); $\mathrm{a}=$ Reflects the percentage of mortality in the day of isolate Chin-IA (I-A) and b = Reflects the speed rate in which mortality decreases.
The meteorological data (temperature, relative humidity, rainfall and solar radiation) during the experimental period were collected at the Embrapa Meteorological Station. A significant interaction between treatments and days in which the soybean leaves were collected after their application was observed, F $(3,6)=8.56, P<0.01$ (Table 1). In addition, there was significative effect of treatments applied into soybean plants against soybean lopper larvae $(P<0.05)$. The mortality of $C$. includens larvae at 0 DAA, was 87.5 and $100 \%$ for the lowest and highest virus concentration used in this study, respectively, whereas all larvae of control treatments remained alive (Table 2).

Table 1. Analysis of variance summary table for mortality data of third-instar Chrysodeixis includens larvae after 0, 2, 4, 6, 8 and 10 days of isolate Chin-IA (I-A) (ChinSNPV) $\left(2 \times 10^{11}\right.$ and $\left.10 \times 10^{11} \mathrm{PIB} \mathrm{ha}^{-1}\right)$ application in soybean plants.

\begin{tabular}{lccc}
\hline Source & DF & Mean square & F-value \\
\hline Treatments & 2 & 0.63194 & $10.7966^{* * *}$ \\
Experimental error & 21 & 0.05853 & \\
\hline Plots & 23 & & $27.3784--$ \\
\hline Evaluation days & 5 & 1.40694 & $8.5676^{* *}$ \\
Int. Treatments x Days & 10 & 0.44028 & 0.05139 \\
Experimental error & 105 & & \\
\hline
\end{tabular}

Total 143

--Treatments are quantitative. $\mathrm{F}$ test is not applicable.

**Significant $\mathrm{F}$-value at the 0.01 level. Coefficient of variation of plots $=28.7 \%$.

Coefficient of variation of subplots $=26.9 \%$.

Table 2. Mean mortality (\%) of third-instar Chrysodeixis includens larvae after 0, 2, 4, 6, 8 and 10 days of isolate Chin-IA (I-A) (ChinSNPV) $\left(2 \times 10^{11}\right.$ and $\left.10 \times 10^{11} \mathrm{PIB} \mathrm{ha}^{-1}\right)$ application in soybean plants.

\begin{tabular}{|c|c|c|c|c|c|c|}
\hline \multirow{2}{*}{ Treatments } & \multicolumn{6}{|c|}{ Days after application (DAA)* } \\
\hline & $\mathbf{0}$ & 2 & 4 & 6 & 8 & 10 \\
\hline Chin-IA (I-A) $2 \times 10^{11} \mathrm{PIB} \mathrm{ha}^{-1}$ & $87.5 \mathrm{~b}$ & $12.5 \mathrm{ab}$ & $0.0 \mathrm{a}$ & $0.0 \mathrm{a}$ & $0.0 \mathrm{a}$ & $0.0 \mathrm{a}$ \\
\hline Chin-IA (I-A) $10 \times 10^{11} \mathrm{PIB} \mathrm{ha}^{-1}$ & $100.0 \mathrm{~b}$ & $37.5 \mathrm{~b}$ & $25.0 \mathrm{a}$ & $0.0 \mathrm{a}$ & $0.0 \mathrm{a}$ & $0.0 \mathrm{a}$ \\
\hline Control & $0.0 \mathrm{a}$ & $0.0 \mathrm{a}$ & $0.0 \mathrm{a}$ & $0.0 \mathrm{a}$ & $0.0 \mathrm{a}$ & $0.0 \mathrm{a}$ \\
\hline
\end{tabular}

*Means followed by the same letter in the column are not statistically different by the Tukey's test at the 0.05 level.

At 2 DAA, only the concentration $10 \times 10^{11} \mathrm{PIB} \mathrm{ha}^{-1}$ was able to cause a significative mortality to the larvae when compared to the control, without differing from that mortality found for the concentration $2 \times 10^{11} \mathrm{PIB}$ $\mathrm{ha}^{-1}$. After larvae ingest the OBs present on plants, they are solubilized in the midgut, releasing the virions who initiate infection in the midgut cells and then, spread through tracheal epidermal cells to other tissues (Harrison and Hoover, 2012). A series of behavioral and morphological changes may be observed between $3^{\text {rd }}$ and $4^{\text {th }}$ days after infection in the insect, such as the reduction in their feeding, retardation of their growth, discoloration and rupture of the integument, culminating in their death (Katsuma, 2015).
From the fourth day after treatments' application, there is no significative effect of mortality to the $C$. includens larvae. The isolate Chin-IA (I-A) reduced its efficiency against $C$. includens larvae in 75 and $62.5 \%$ to the lowest and highest concentrations, respectively, between 0 and 4 days after application. These findings are similar to that found by Young and Yearian (1974) when the virus B. heliothis lost around $75 \%$ of its original activity into control Heliothis virescens (Fabricius, 1781) (Lepidoptera: Noctuidae) after 48 hours exposure on the soybean leaves in natural conditions. The purified B. anticarsia also had $50 \%$ of reduction in the control of Anticarsia gemmatalis (Hübner, 1818) (Lepidoptera: Noctuidae) in the second day after to be applied in soybean plants (Batista Filho et al., 1992). 
The exponential decay model provided for the lowest Chin-IA (I-A) concentration the values of 87.53 \pm 0.86 and $0.99 \pm 0.03$ for $\mathrm{a}$ and $\mathrm{b}$ parameters, respectively, and a value of coefficient of determination $\left(\mathrm{R}^{2}\right)$ equal 0.99 (Figure 1). Regarding the highest ChinIA (I-A) concentration, the values for $a$ and $b$ parameters were $99.73 \pm 5.74$ and $0.45 \pm 0.05$, respectively, with a $\mathrm{R}^{2}$ of 0.98 . Thus, it was observed low standard error values to the both parameters evaluated and high $\mathrm{R}^{2}$, indicating that the model regression chosen have fit very well.
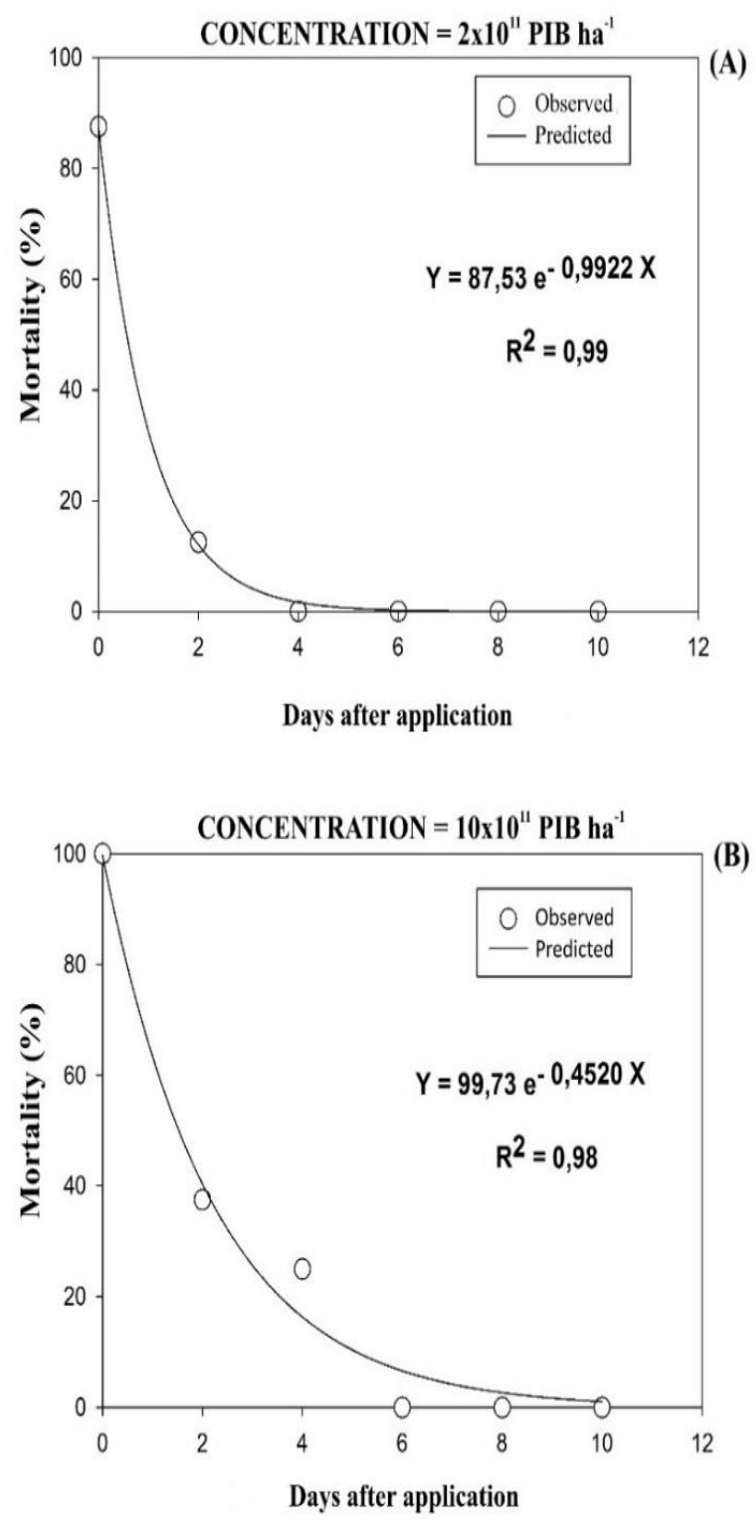

Figure 1. Mean mortality (\%) observed and predicted with regression analysis of third-instar Chrysodeixis includens larvae after 10 days of isolate Chin-IA (I-A) (ChinSNPV) $\left(2 \times 10^{11}\right.$ and $\left.10 \times 10^{11} \mathrm{PIB} \mathrm{ha}^{-1}\right)$ to be applied in soybean plants.

The persistence and activity of the virus studied here may be compromised by several factors. Host plants plays an important role in the efficiency of ChinNPV against $C$. includens producing some chemical substances responsible for the loss of viral activity
(Stevenson et al., 2010). Climatic conditions are also recurring concern when microorganisms are exposure to natural conditions affecting their performance, persistence, virulence and dispersion (Jaronski, 2010). During the experimental period, the isolate Chin-IA (IA) was exposure to mean temperatures ranging from 25.8 to $29.1^{\circ} \mathrm{C}$ (Table 3 ) falling into favorable limits for this pathogen according to Alves and Lecuona (1998). Similar conditions were not harmful to the activity of virus B. anticarsia (Johnson et al., 1982). For this reason, we believe that the temperature did not influence in the loss of activity of isolate used. In addition, theses temperatures are pretty convenient since the $C$. includens outbreaks are related with warmer and wetter periods of the year as well as higher availability of host plants (Santos et al., 2017). Virus has shown to be the less affected by the relative humidity of the air among the microorganisms control agents (Alves and Lecuona, 1998). During the experiment, the air relative humidity remained above of $50 \%$ achieving a peak of $73 \%$ in the $5^{\text {th }}$ day due to rain. Considering that around $70 \%$ of efficiency of our nucleopolyhedrovirus was reduced during the four first days, this factor does not seem to have had expressive influence over time.

The most likely reason for the loss of activity of ChinNPV (I-A) against soybean lopper larvae may be attributed to the solar radiation, in which it ranged from 8.5 to $15.7 \mathrm{MJm}^{2}$ day $^{-1}$ during the period that the virus was exposure on the plants. Ultraviolet radiation has been extensively reported as the major cause of activity loss in field-applied baculoviruses. The UV acts directly on the nucleic acids causing alterations or destroying them (Grzywacz, 2016), being necessary the reapplication of virus in the field at 7-10 days interval (Jeyarani et al., 2013). In this scenario, it is important that virus be applied at sundown to reduce the effects of UV radiation on the activity of them, ensuring its efficiency during the first night after application on the crop (Silva and Moscardi, 2002). The time of application used in this study may have been responsible for the fast effectiveness reduction of ChinNPV (I-A) in control C. includens larvae. According Silva and Moscardi (2002), the highest efficacy of the AgMNPV (nucleopolyhedrovirus of $A$. gemmatalis) was observed for applications made at 2:00 a.m. or 8:00 p.m. compared to those made at 8:00 a.m. and 2:00 p.m. Despite the loss of the activity of the baculovirus applied, its polyhedral bodies might be continuously renewed through dead caterpillars in natural conditions (Moscardi et al., 2011). 
Table 3. Meteorological data collected at the Embrapa Meteorological Station during the experimental period.

\begin{tabular}{|c|c|c|c|c|c|c|}
\hline \multirow{2}{*}{ Experimental period (DAA)* } & \multirow{2}{*}{ Solar radiation ${ }^{1}$} & \multirow{2}{*}{ R.H $\mathbf{H}^{1}$} & \multicolumn{3}{|c|}{ Temperature $^{1}$} & \multirow{2}{*}{ Rainfall $^{1}$} \\
\hline & & & $\max$ & $\min$ & mean & \\
\hline 0 & 15.7 & 56 & 34.2 & 18.9 & 26.2 & 0.0 \\
\hline 1 & 11.9 & 61 & 32.4 & 19.5 & 26.3 & 0.0 \\
\hline 2 & 13.7 & 59 & 34.9 & 19.7 & 27.0 & 0.0 \\
\hline 3 & 13.1 & 55 & 35.6 & 19.5 & 28.0 & 0.0 \\
\hline 4 & 15.0 & 53 & 36.6 & 21.8 & 29.1 & 0.0 \\
\hline 5 & 10.8 & 73 & 35.8 & 20.4 & 25.8 & 9.4 \\
\hline 6 & 14.2 & 73 & 34.6 & 19.1 & 26.1 & 0.0 \\
\hline 7 & 14.4 & 63 & 36.1 & 21.2 & 28.7 & 0.0 \\
\hline 8 & 8.5 & 74 & 34.0 & 23.7 & 27.2 & 0.0 \\
\hline 9 & 15.4 & 69 & 34.5 & 21.8 & 27.6 & 0.0 \\
\hline 10 & 12.3 & 70 & 33.4 & 20.8 & 26.6 & 0.2 \\
\hline Mean & 13.2 & 64 & 34.7 & 20.6 & 27.1 & 0.9 \\
\hline
\end{tabular}

*DAA=Days after treatments' application.

${ }^{1}$ Solar radiation $\left(\mathrm{MJm}^{2} \mathrm{day}^{-1}\right)$; Relative humidity $(\%)$; Temperature $\left({ }^{\circ} \mathrm{C}\right)$; and Rainfall $(\mathrm{mm})$.

We have shown in the present study that two concentrations of isolate Chin-IA (I-A) (ChinSNPV) lost, on average, $70 \%$ of their efficiency into control the third-instar $C$. includens larvae after 4 days of application in soybean plants. Solar radiation and time of application may have had strong influence in the results obtained here. The implementation of ChinSNPV in soybean integrated pest management (IPM) programs is a sustainable alternative where its correct use, whether associated with other agricultural practices may bring successful results and hence, facilitated farmer acceptance.

\section{Acknowledgements}

FUNDECT (Fundação de Apoio ao Desenvolvimento do Ensino, Ciência e Tecnologia do Estado do Mato Grosso do Sul) and CAPES (Coordenação de Aperfeiçoamento de Pessoal de Nível Superior).

\section{Bibliographic References}

Alexandre, T.M., Ribeiro, Z.M.A., Craveiro, S.R., Cunha, F., Fonseca, I.C., Moscardi, F., Castro, M.E.B., 2010. Evaluation of seven viral isolates as potential biocontrol agents against Pseudoplusia includens (Lepidoptera: Noctuidae) caterpillars. Journal of Invertebrate Pathology, 105, 98-104.

Alves, S.B., Lecuona, R.E., 1998. Epizootiologia aplicada ao controle microbiano, in: Alves, S. B. (Ed.), Controle microbiano de insetos. 2nd.ed. Piracicaba, FEALQ, pp. 97169.
Batista Filho, A., Alves, S.B., Augusto, N.T., Cruz, B.P.B., 1992. Persistência de duas formulações de Baculovirus anticarsia sobre folhas de soja, em condições de campo. Pesquisa Agropecuária Brasileira, 27, 1005-1009.

Beas-Catena. A., Sánchez-Mirón, A., García-Camacho, F., Contreras-Gómez, A., Molina-Grima, E., 2014. Baculovirus Biopesticides: An Overview. The Journal of Animal \& Plant Sciences, 24, 362-373.

Bernal, A., Simón, O., Williams, T., Caballero, P., 2014. Stage-specific insecticidal characteristics of a nucleopolyhedrovirus isolate from Chrysodeixis chalcites enhanced by optical brighteners. Pest Management Science, 70, 798-804.

Bernardi, O., Malvestiti, G.S., Dourado, P.M., Oliveira, W.S., Martinelli, S., Berger, G.U., Head, G.P., Omoto, C., 2012. Assessment of the high-dose concept and level of control provided by MON $87701 \times$ MON 89788 soybean against Anticarsia gemmatalis and Pseudoplusia includens (Lepidoptera: Noctuidae) in Brazil. Pest Management Science, 68, 1083-1091.

CONAB. Companhia Nacional de Abastecimento (Brasil), 2018. Acompanhamento de safra brasileira: grãos, v. 5, n.7, Safra 2017/18 - Sétimo levantamento, Brasília, p. 1-139.

Craveiro, S.R., Melo, F.L., Ribeiro, Z.M.A., Ribeiro, B.M., Báo, S.N., Inglis, P.W., Castro, M.E.B., 2013. Pseudoplusia includens single nucleopolyhedrovirus: Genetic diversity, phylogeny and hypervariability of the pif- 2 gene. Journal of Invertebrate Pathology, 114, 258-267.

Craveiro, S.R., Inglis, P.W., Togawa, R.C., Grynberg, P., Melo, F.L., Ribeiro, Z.M.A., Bergmann, M.R., Báo, S.N., Castro, M.E.B., 2015. The genome sequence of Pseudoplusia includens single nucleopolyhedrovirus and an analysis of p26 gene evolution in the baculoviruses. BMC Genomics, 16, 127. 
Czepak, C., Albernaz, K.C., 2014. Manejo avançado: Surtos de falsa-medideira. Cultivar Grandes Culturas, 178, 20-24.

Gifani, A., Marzban, R., Safekordi, A., Ardjmand, M., Dezianian, A., 2015. Ultraviolet protection of nucleopolyhedrovirus through microencapsulation with different polymers. Biocontrol Science and Technology, 25, 814-827.

Grzywacz, D., 2016. Basic and applied research: Baculovirus, in: Lacey, L.A., (Ed.), Microbial control of insect and mite pests: From theory to practice. 1st.ed. Yakima, Academic Press, pp. 27-46.

Harrison, R., Hoover, K., 2012. Baculoviruses and Other Occluded Insect Viruses, in: Vega, F.E., Kaya, H.K., (Eds.), Insect Pathology. Academic Press, Elsevier, pp. 73-131.

Jaronski, S.T., 2010. Ecological factors in the inundative use of fungal entomopathogens. BioControl, 55, 159-185.

Jeyarani, S., Sathiah, N., Karuppuchamy, P., 2013. An in vitro method for increasing UV-tolerance in a strain of Helicoverpa armigera (Lepidoptera: Noctuidae) Nucleopolyhedrovirus. Biocontrol Science and Technology, 23, 305-316.

Johnson, D.W., Boucias, D.G., Barfield, C.S., Allen, G.E., 1982. A temperature dependent model for a nucleopolyhedrosis virus of the velvetbean caterpillar, Anticarsia gemmatalis (Lepidoptera: Noctuidae). Journal of Invertebrate Pathology, 40, 292-298.

Katsuma, S., 2015. Baculovirus controls host caterpillars by manipulating host physiology and behavior. AGri-Bioscience Monographs, 5, 1-27.

Moscardi, F., Souza, M.L., Castro, M.E.B., Moscardi, M., Szewczyk, B., 2011. Baculovirus pesticides: present state and future perspectives, in: Ahmad, I., Ahmad, F., Pichtel, J., (Eds), Microbes and Microbial Technology. New York, Springer, pp. 415-445.
Santos, S.R., Specht, A., Carneiro, E., Paula-Moraes, S.V., Casagrande, M.M., 2017. Interseasonal variation of Chrysodeixis includens (Walker, [1858]) (Lepidoptera: Noctuidae) populations in the Brazilian Savanna. Revista Brasileira de Entomologia, 61, 294-299.

Silva, F.A.S., Azevedo, C. A. V. de., 2002. Versão do programa computacional ASSISTAT para o sistema operacional Windows. Revista Brasileira de Produtos Agroindustriais, 4, 71-78.

Silva, M.T.B., Moscardi, F., 2002. Field Efficacy of the Nucleopolyhedrovirus of Anticarsia gemmatalis Hübner (Lepidoptera: Noctuidae): Effect of formulations, water $\mathrm{pH}$, volume and time of application, and type of spray nozzle. Neotropical Entomology, 31, 75-83.

Stevenson, P.C., D'cunha, R.F., Grzywacz, D., 2010. Inactivation of baculovirus by isoflavonoids on chickpea (Cicer arietinum) leaf surfaces reduce the efficacy of Nucleopolyhedrovirus against Helicoverpa armigera. Journal of Chemical Ecology, 36, 227-235.

Sutanto, K.D., El Salamouny, S., Tufail, M., Rasool, K.G., Sukirno, S., Shepard, M., Shapiro, M., Aldawood, A.S., 2017. Evaluation of Natural Additives to Enhance the Persistence of Spodoptera littoralis (Lepidoptera: Noctuidae) Nucleopolyhedrovirus (SpliMNPV) Under Field Conditions in Saudi Arabia. Journal of Economic Entomology, 110, 924930.

Young, S.Y., Yearian, W.C., 1974. Persistence of Heliothis VPN on foliage of cotton, soybean, and tomato. Environmental Entomology, 3, 253-255.

Wu, Z.W., Fan, J.B., Yu, H., Wang, D., Zhang, Y.L., 2015. Ultraviolet protection of the Cydia pomonella granulovirus using zinc oxide and titanium dioxide. Biocontrol Science and Technology, 25, 97-107. 